NBER WORKING PAPER SERIES

HOW DIFFERENT IS JAPANESE

CORPORATE FINANCE? AN

INVESTIGATION OF THE INFORMATION

CONTENT OF NEW SECURITY ISSUES

Jun-Koo Kang

René M. Stulz

Working Paper No. 4908

\author{
NATIONAL BUREAU OF ECONOMIC RESEARCH \\ I050 Massachusens Avenue \\ Cambridge, MA 02138 \\ October 1994
}

Kang is grateful for tinancial suppor from the URI Faculty Development Research (irant Program. We are grateful for comments from Ron Masulis, Bill Schwer, Jerry Warner and participants at seminars at DePaul University, Harvard University and Vanderbilt University. This paper is part of NBER's research program in Corporate Finance. Any opinions expre ssed are those of the authors and not those of the National Bureau of Economic Research.

(c) 1994 by Jun-Koo Kang and René M. Stulz. All rights reserved. Shor sections of texı. not to exceed two paragraphs, may be quoted without explicit permission provided that full credit, including (?) notice, is given to the source. 


\title{
HOW DIFFERENT IS JAPANESE \\ CORPORATE FINANCE? AN \\ INVESTIGATION OF THE INFORMATION \\ CONTENT OF NEW SECURITY ISSUES
}

\begin{abstract}
This paper studies the shareholder wealth effects associated with 875 new security issues in Japan from January 1, 1985 to May 31, 1991. The sample includes public equity, private equity, rights offerings, straight debt, warrant debt and convertible debt issues. Contrary to the U.S., the announcement of convertible debt issues is accompanied by a significant positive abnormal return of $1.05 \%$. The announcement of equity issues has a positive abnormal return of $0.45 \%$, significant at the 0.10 level, but this positive abnormal retum can be attributed to one year in our sample and is offset by a negative issue date abnomal retum of $-1.01 \%$. The abnormal returns are negatively related to firm size, so that for equity issues (but not for convertible debt issues), large Japanese firms have significant negative announcement abnormal returns. Our evidence is consistent with the view that Japanese managers decide to issue shares based on different considerations than American managers.

Jun-Koo Kang

Department of Finance

College of Business Administration

The University of Rhode Island

Kingston, RI $0288 \mathrm{I}$

René M. Stulz

Department of Finance

Max M. Fisher College of Business

The Ohio State University

1775 S. College Road, Room 314

Columbus, OH 43210

and NBER
\end{abstract}




\section{Section 1. Introduction.}

The stock-price reaction to new security issues by American firms has been examined extensively. The existing literature shows convincingly that the announcement of new public domestic (as opposed to offshore) security issues by U.S. firms is associated with a decrease in the firms' stock price that increases with the risk of the secunity issued: there is no significant effect for AAA debt, a significant drop for convertible debt, and a larger drop for equity issues.' The most widely accepted interpretation for these results is that new issues convey information about the value of the issuing firm's equity. If managers maximize the wealth of existing shareholders, they avoid issuing securities at prices such that the buyers of new securities would benefit at the expense of the existing shareholders. Therefore, an issue of a risky security is evidence that managers believe that the firm is not undervalued too much by the market.

It is widely argued that managers in Japan pursue different objectives than managers in the U.S. Some view this difference in a favorable light, arguing that Japanese managers do not have to focus on short-term results and can take a long view which allows them to produce more wealth for shareholders. Others view this difference as evidence that Japanese managers are more interested in pursuing objectives such as the maximization of market share than in maximizing shareholder wealth. The purported difference in the objectives of managers between Japan and the U.S. makes Japan a good testing ground for corporate finance theories developed in the U.S. In particular, similar stock-price reactions to new security issues in the two countries would make it harder to believe that there are significant differences in managerial incentives between the two countries.

\footnotetext{
${ }^{1}$ See Smith (1986) and Masulis (1988) for a review of the evidence and of its interpretation. Shyam-Sunder (1991) finds that the stock-price reaction to debt issues is not related to the rating.

${ }^{2}$ See, for instance, Porter (1992) and Kester (1991). In contrast, Kaplan (1994) stresses the commonalities in managerial compensation and tumover between Japan and the U.S.
} 
There exists some indication that stock-price reactions to new issues are different for Japanese firms. Kato and Shalheim (1992) show that the stock-price reaction to equity issues is significantly positive from January 1984 to March $1988 .{ }^{3}$ However, their study uses as the event date the Board meeting date when the firm decides to issue equity, which makes their evidence not directly comparable to American evidence which uses event dates obtained from the Wall Street Joumal. Further, they do not exclude firms which simultaneously announce a stock dividend from their sample.

Kang, Kim, Park and Stulz (1994) investigate the stock-price reaction to offshore warrant bond issues for Japanese firms using announcements in the Financial Times. Their study has the advantage of using event dates similar to the ones used for offshore issues by American firms. However, its disadvantage is that it focuses on offshore markets and does not include equity. Nevertheless, they find a positive significant stock-price reaction to warrant bond issues and argue that Japanese firms do not behave like American firms in their decision to issue new securities. American firms issue risky securities such as stock and convertible debt following periods of positive excess returns. In contrast, excess returns prior to warrant bond issues by Japanese firms are insignificantly negative. This piece of evidence suggests that Japanese managers do not care as much about the wealth redistribution effects of new issues. Kang et al. (1994) argue that one possible explanation is that corporate control arrangements in Japan are such that the long-term investors are like the fixed-fraction investors analyzed in Admati and Pfleiderer (1994), i.e., investors who hold a fixed fraction of all the firm's secunities and receive

\footnotetext{
${ }^{3}$ Hanaeda (1993) investigates the stock-price reaction of seasoned equity issues from 1975 to 1983. His study provides estimates of monthly market model prediction errors, where month zero is the month of the offering. He finds a positive abnormal return for the offering month and the month before of slightly more than one percent. He provides no estimates of statistical significance.
} 
a fixed fraction of all its payouts. This is because (1) these investors want to keep their stake in the firm constant, so that they participate in new issues, (2) some of them hold debt as well as equity, and (3) these investors have business relationships with the firms in which they invest, so that they gain when these firms invest even if their shares do not increase in value. ${ }^{4}$ If it is correct to view Japanese long-term investors as fixed-fraction investors and if managers maximize the wealth of these investors, the existing theoretical literature suggests that security issues should not be informative about the mispricing of existing securities.

In this paper, we investigate further the stock-price reaction to new issues in Japan by using a large database of new issues for which we have announcement dates from the moming edition of the Nihon Kelzal Shinbun, which is the equivalent of the Wall Street Joumal for Japan. This sample covers the period from January 1, 1985, to May 31, 1991. Hence, the sample allows us to investigate whether the abnormal retums to new issue announcements are related to the bull market. With this database, our announcement dates and sample selection procedures are equivalent to what researchers have used for U.S. domestic issues. Our sample includes public equity, private equity, rights offerings, straight debt, warrant debt, and convertible debt issues. The number of straight debt and warrant debt issues is too small to permit a detailed analysis. however. We first use our sample to establish that stock-price reactions to new issues are indeed different for Japanese firms. In particular, we find positive announcement retums for both equity issues and convertible issues.

We then explore four possible interpretations for the difference in results:

1. Institutional differences and/or market Inefficiencies. The institutional setting for

\footnotetext{
4 See Gerlach (1992), Gilson and Roe (1993) and Kester (1991) for analyses which stress the complex relationships between long-term investors in Japan and the firms they invest in.

${ }^{5}$ See Dybvig and Zender (1991), Persons (1994) and Admati and Pfleiderer (1994).
} 
security issues in Japan is strongly different from the one in the U.S. It could therefore be that the Japanese institutional setting allows firms to manipulate security prices around security offerings. Alternatively, the disclosure process could be such that issues are not a surprise when announced. Our evidence is inconsistent with the view that the announcement is fully anticipated since we find significant positive abnormal returns on the announcement date. We find a significant negative abnormal retum at the offering date of equity issues which is much larger in absolute value than the abnormal retum observed in the U.S. and which is larger than the announcernent abnormal return. We do not find this pattern with convertible bond issues: for convertible bond issues there is a positive announcement effect and a positive issue date return.

2. Deregulation effects. The Eighties are an abnormal period in Japan because of deregulation. We find the stock-price reaction for convertible debt issue announcements of firms which have no convertible debt on their balance sheet is significantly higher than the stock-price reaction for issues by other firms. A plausible interpretation of this result is that, because of the relaxation of eligibility criteria for the issuance of convertible debt issues, a firm's first convertible debt issue provides information to the markets that the firm is becoming more independent from banks.

3. "Bubble economy" effects. The Japanese stock market experienced very large positive returns during the second half of the 1980 s followed by a spectacular crash at the beginning of the 1990s, so that the Nikkei 225 index tripled from 1985 to 1989 and then lost the gains it had made. Some observers believe that the increase in the Japanese stock market corresponds to a "bubble" that cannot be explained by changes in fundamentals.' These observers might argue that positive abnormal returns to risky secunity issues is just another

\footnotetext{
See Hoshi, Kashyap and Schartstein (1993).

'See French and Poterba (1991) for a discussion of this period.
} 
example of irrationality associated with the "bubble" economy and point to the fact that Kato and Schalheim (1992) find negative abnormal returns for equity issues in the first half of the 1970 s Though the positive stock-price reactions associated with equity issue announcements are highest in 1985 and 1987 in our sample, our evidence does not indicate that abnormal retums in 1990 and 1991 are similar to those observed in the U.S. and, consequently, the differences in abnormal retums between the two countries persist after the end of the bull market in Japan.

4. Differences in corporate control mechanisms. If differences in control mechanisms explain part or all of our results, one would expect that the Japanese firms which are most similar to U.S. firms should have stock-price reactions similar to U.S. firms. We first explore whether nonKeiretsu firms have stock-price reactions similar to those of U.S. firms and find that in our sample the distinction between Keiretsu and non-Keiretsu firms is largely uninformative. We then explore whether large Japanese firms, where management is presumably less constrained by the web of relationships in which Japanese firms operate, have different stock-price reactions. There we find strong differences. In fact, large Japanese corporations have stock-price reactions closer to those of American corporations for equity issues. However, large Japanese corporations still have positive stock-price reactions to convertible issues, albeit significantly smaller than for small corporations. Finally, we explore the relation between abnormal retums and the extent to which a firm is financed by bank loans. For equity issues, firms with more bank loans have more positive abnormal returns. Firms with no reported bank loans have an average abnormal return of $-0.92 \%$ on announcement of an equity issue in contrast to a matched sample of firms of similar size issuing equity in the same year which has an average abnormal retum of $1.60 \%$. However. bank loans are not helpful in understanding the cross-sectional variation in the abnormal returns for convertible bond issue announcements.

The paper proceeds as follows. We describe our sample in section 2. In section 3, we 
provide abnormal returns for various subperiods of interest. In section 4 , we explore possible explanations for the stock-price reactions we observe. We conclude in section 5 .

\section{Section 2. The sample of issues and firm characteristics.}

To obtain our sample, we proceed as follows. We start from the list of new issues from the Tokyo Stock Exchange (TSE) Annual Securities Statistics for the period from January 1, 1985. to May 31, $1991 .{ }^{\circ}$ We then exclude all new issues which do not satisfy the following criteria:

1) The issuing firm is listed on the TSE and stock price data are available on the daily retums files from the Pacific-Basin Capital Market (PACAP) Research Center. The daily retums files includes retums for alt First and Second Section stocks on the Tokyo Stock Exchange. We exclude utilities and financial companies (the required data for financial companies are not available on the PACAP files which are used in this study).

2) The date of the initial public announcement is available from the morning edition of the Nihon Kelzai Shinbun.

3) The issue involves a single type of security, is not accompanied by a stock dividend. and the firm does not release important information, such as eamings, with the announcement of the issue. (Firms which simultaneously issue the same type of security on the domestic market and offshore are excluded.)

${ }^{8}$ Kato and Schallheim $(1992,1993)$ use the Commercial Law Revlow to construct samples of private and public equity issues. Their study has only three full years which overtap with our sample, namely 1985, 1986 and 1987 . For these years, they have 19 private placements and 76 public equity issues in contrast to our 31 private placements and 37 public issues which are not rights offerings. The samples differ because (1) we require an announcement in the Nihon Kelzai Shinbun, (2) they consider only firms listed on the First Section of the Tokyo Stock Exchange. (3) we exclude firms which simultaneously announce a stock dividend and (4) we exclude issues by utilities and financial companies. The second difference may explain their smaller number of private issues, whereas the exclusion of firms with simultaneous stock dividends and of financial companies may help explain why we have fewer public equity issues. 


\section{Table 1}

Distribution of announcements of security offerings by type and by year

The announcements are by firms listed on the Tokyo Stock Exchange for which an event date could be obtained from the Ninon Keizal Shinbun during the period from January 1, 1985 to May 31, 1991 and for which information is available from the PACAP files.

\begin{tabular}{|l|r|r|r|r|r|r|r|r||}
\hline \multirow{2}{*}{$\begin{array}{l}\text { Type of offe- } \\
\text { ring }\end{array}$} & \multicolumn{7}{|c|}{ Year } & \multirow{2}{*}{ Total } \\
\cline { 2 - 9 } & 1985 & 1986 & 1987 & 1988 & 1989 & 1990 & 1991 & \\
\hline Stock, public & 9 & 9 & 19 & 33 & 82 & 30 & 3 & 185 \\
\hline Stock, private & 13 & 9 & 9 & 13 & 10 & 9 & 6 & 69 \\
\hline Stock, rights & 4 & 2 & 0 & 1 & 5 & 12 & 4 & 28 \\
\hline Straight bond & 8 & 2 & 0 & 0 & 0 & 0 & 3 & 13 \\
\hline Warrant bond & 0 & 4 & 1 & 0 & 5 & 7 & 2 & 19 \\
\hline $\begin{array}{l}\text { Convertible } \\
\text { bond }\end{array}$ & 70 & 73 & 122 & 117 & 124 & 42 & 13 & 561 \\
\hline Total & 104 & 99 & 151 & 164 & 226 & 100 & 31 & 875 \\
\hline
\end{tabular}


These sample selection criteria produce a sample of 875 issues described in table 1 . Our sample contains mostly convertible debt issues and public equity issues. The predominance of convertible debt issues is not surprising given the aggregate statistics on security offerings published by Niimi (1992a). Niimi (1992a) shows that convertible debt is the principal source of public funds for Japanese companies throughout the Eighties. Our sample understates the importance of equity-linked debt for Japanese firms since it includes only domestic issues. As discussed in Kang et al. (1994), dollar-denominated warrant bond issues were a major source of funds for Japanese companies during the 1980s. We found few straight debt issues. In addition, we found almost no warrant bonds. Again, this is not particularly surprising in light of the statistics in Niimi (1992a). There is some clustering of the issues during the height of the bubble economy period. More than $40 \%$ of the equity issues and about $25 \%$ of the convertible issues are in 1989 .

Hanaeda (1993) shows that firms issued only rights offenings in the 1950s, but that over time the proportion of underwritten equity offerings among equily issues increased to reach the point where most equity issues are underwnitten offerings. This shift towards underwritten offerings has made Japanese firms more similar to American firms in their issuing practices. It is interesting that more than half of the rights offerings in our sample take place after the spectacular growth in the Nikkei 225 index has stopped. Based on our sample, we cannot tell whether this corresponds to a resurgence of rights offerings or to the unique circumstances associated with the end of the "bubble economy".

Table 2 shows the characteristics of firms issuing the vanious types of securities. These financial data are obtained from the PACAP Research Center database and from the Analyst's

\footnotetext{
'Hanaeda (1993) provides evidence on the total number of each type of equity issue for each year from 1970 to 1990 . He finds that the proportion of rights offerings as a fraction of the total number of issues is larger in 1990 than in any year duning the 1980 s, but he does not note this fact in his analysis.
} 


\begin{tabular}{|c|c|c|c|c|c|c|}
\hline \multicolumn{7}{|c|}{$\begin{array}{l}\text { Table } 2 \\
\text { Characteristics of the issuing firms } \\
\text { The announcements are by firms listed on the Tokyo Stock Exchange for } \\
\text { which an event date could be obtained from the Nihon Keizal Shinbun } \\
\text { during the period from January } 1,1985 \text { to May } 31,1991 \text { and for which } \\
\text { information is available from the PACAP files. The Yen amounts are in billion } \\
\text { Yen. Beta is estimated from -220 to }-20 \text {, where date } 0 \text { is the announcement } \\
\text { date of the issue. The } Q \text { proxy is (total liabilities + market value of equi- } \\
\text { ty)/(total liabilities + book value of equity). Leverage is measured as (total } \\
\text { liabilities)/(total liabilities + market value of equity). The first number in each } \\
\text { cell is the mean and the second is the median. }\end{array}$} \\
\hline \multirow[t]{3}{*}{ Vaniable } & \multicolumn{6}{|c|}{ Type } \\
\hline & \multicolumn{3}{|c|}{ Common stock } & \multirow{2}{*}{$\begin{array}{l}\text { Strai- } \\
\text { ght } \\
\text { bond } \\
\text { (13) }\end{array}$} & \multirow{2}{*}{$\begin{array}{c}\text { Warr- } \\
\text { ant } \\
\text { bond } \\
(19)\end{array}$} & \multirow{2}{*}{$\begin{array}{c}\text { Con- } \\
\text { vertible } \\
\text { bond } \\
(561)\end{array}$} \\
\hline & $\begin{array}{l}\text { Public } \\
\text { (185) }\end{array}$ & $\begin{array}{l}\text { Private } \\
\text { (69) }\end{array}$ & $\begin{array}{l}\text { Rights } \\
(28)\end{array}$ & & & \\
\hline Amount offered & $\begin{array}{r}16 \\
5 \\
\end{array}$ & $\begin{array}{l}7 \\
3 \\
\end{array}$ & $\begin{array}{l}6 \\
4 \\
\end{array}$ & $\begin{array}{l}27 \\
10\end{array}$ & $\begin{array}{l}31 \\
30\end{array}$ & $\begin{array}{l}24 \\
15\end{array}$ \\
\hline $\begin{array}{l}\text { Market value of } \\
\text { equity }\end{array}$ & $\begin{array}{r}185 \\
46 \\
\end{array}$ & $\begin{array}{l}56 \\
30 \\
\end{array}$ & $\begin{array}{l}76 \\
47 \\
\end{array}$ & $\begin{array}{l}778 \\
140\end{array}$ & $\begin{array}{l}411 \\
340\end{array}$ & $\begin{array}{l}346 \\
142 \\
\end{array}$ \\
\hline $\begin{array}{l}\text { Amount /market } \\
\text { value of equity }\end{array}$ & $\begin{array}{l}0.14 \\
0.13\end{array}$ & $\begin{array}{l}0.22 \\
0.13\end{array}$ & $\begin{array}{l}0.09 \\
0.09\end{array}$ & $\begin{array}{l}0.04 \\
0.03\end{array}$ & $\begin{array}{l}0.09 \\
0.09\end{array}$ & $\begin{array}{l}0.12 \\
0.10\end{array}$ \\
\hline PE ratio & $\begin{array}{l}54.54 \\
47.98 \\
\end{array}$ & $\begin{array}{l}328.98 \\
131.97\end{array}$ & $\begin{array}{r}117.03 \\
55.86 \\
\end{array}$ & $\begin{array}{l}71.24 \\
39.34\end{array}$ & $\begin{array}{l}67.76 \\
48.90\end{array}$ & $\begin{array}{l}55.51 \\
44.84\end{array}$ \\
\hline Beta & $\begin{array}{l}1.02 \\
1.00\end{array}$ & $\begin{array}{l}1.06 \\
1.07 \\
\end{array}$ & $\begin{array}{l}1.15 \\
0.94 \\
\end{array}$ & $\begin{array}{l}1.05 \\
0.86 \\
\end{array}$ & $\begin{array}{l}1.27 \\
1.01\end{array}$ & $\begin{array}{l}1.15 \\
1.10\end{array}$ \\
\hline Q proxy & $\begin{array}{l}1.94 \\
1.81 \\
\end{array}$ & $\begin{array}{l}2.14 \\
1.74\end{array}$ & $\begin{array}{l}2.19 \\
1.93\end{array}$ & $\begin{array}{l}1.66 \\
1.21\end{array}$ & $\begin{array}{l}1.84 \\
1.86\end{array}$ & $\begin{array}{l}1.97 \\
1.79\end{array}$ \\
\hline Leverage ratio & $\begin{array}{l}0.42 \\
0.40\end{array}$ & $\begin{array}{l}0.46 \\
0.44\end{array}$ & $\begin{array}{l}0.40 \\
0.41\end{array}$ & $\begin{array}{l}0.55 \\
0.65\end{array}$ & $\begin{array}{l}0.38 \\
0.35\end{array}$ & $\begin{array}{l}0.36 \\
0.33\end{array}$ \\
\hline
\end{tabular}


Guide by Daiwa Institutes of Research Ltd. We use the 1985 edition of Industrial Groupings in Japan by Dodwell Marketing Consultants to determine each firm's Keiretsu affiliation. It is apparent from table 2 that, compared to firms issuing convertible debt, firms issuing equity are smaller, and that the size of the issue is large relative to the value of existing equity. Priceeamings ratios are similar across firms issuing equity and convertible debt in public offerings, but obviously are high compared to the U.S.. Our proxy for Tobin's $Q$ is similar across firms. Leverage ratios are slightly higher for firms issuing equity. These measures use the market value of equity in the denominator. which explains why they are not higher.

\section{Section 3. The stock-price reaction to security offerings.}

In table 3, we provide estimates of excess retums over various subperiods. The excess relurns are computed in the following way. We group the TSE securities into ten equal size control portfolios ranked according to their Scholes and Williams (1977) beta estimates computed with respect to the PACAP equally-weighted portfolio for Japan. Then, we assign the stock of ezrt : riugng firm to one nf these portfolios. We compute the abnormal retum on a particular day by takin, the difference between the return on the issuing firm's stock and an equally-weighted centro! rintfolio. Though the event period comprising the day of the announcement and the day befcre is the one researchers sypically focus on for U.S. studies, we pay more attention to the fortatich ircludes the day after the announcement. Including this additional day eliminates s.mie of the microstructure effects which could arise because of order flow imbalances on the day of the announcement and because of the existence of price limils.

We discuss the abnormal retum estimates for each type of issue in tum:

1. Public equity offerings. The announcement retum, defined as the cumulative retum for the three-day window surrounding the publication of the announcement, is significantly positive 


\begin{tabular}{|c|c|c|c|c|c|c|}
\hline \multicolumn{7}{|c|}{$\begin{array}{l}\text { Table } 3 \\
\text { Average cumulative abnormal returns around the announcement (AD) and issuance } \\
\text { (ID) of securlty offerings } \\
\text { The sample includes } 875 \text { announcements between January } 1,1985 \text { and May } 31,1991 \text { by } \\
\text { firms listed on the Tokyo Stock Exchange. The daily excess retum is the issuing firm's } \\
\text { retum minus the return on a control portfolio with a similar Scholes-Williams beta estimate. } \\
\text { Medians and t-statistics are in parentheses. * and *** indicate significance of the sign - } \\
\text { rank test at the } 0.10,0.05 \text { and } 0.01 \text { levels, respectively. }\end{array}$} \\
\hline \multirow[t]{3}{*}{ Interval } & \multicolumn{6}{|c|}{ Type of issue } \\
\hline & \multicolumn{3}{|c|}{ Common stock } & \multirow{2}{*}{$\begin{array}{l}\text { Straight } \\
\text { debt } \\
\begin{array}{c}\text { Public } \\
\text { offering } \\
(13)\end{array} \\
\end{array}$} & \multirow{2}{*}{$\begin{array}{l}\text { Warrant } \\
\text { bond } \\
\begin{array}{c}\text { Public } \\
\text { offering } \\
\text { (19) }\end{array} \\
\end{array}$} & \multirow{2}{*}{$\begin{array}{l}\text { Conver- } \\
\text { tible } \\
\text { bond }\end{array}$} \\
\hline & $\begin{array}{c}\text { Public } \\
\text { offering } \\
(185)\end{array}$ & $\begin{array}{c}\text { Private } \\
\text { offering } \\
(69)\end{array}$ & $\begin{array}{c}\text { Rights } \\
\text { offering } \\
(28)\end{array}$ & & & \\
\hline $\begin{array}{l}A D-60 \text { to } \\
A D-2\end{array}$ & $\begin{array}{l}-0.69 \% \\
(-0.58) \\
(-0.83) \\
\end{array}$ & $\begin{array}{l}11.85 \% \\
(3.28)^{* \cdots} \\
(3.78) \\
\end{array}$ & $\begin{array}{l}10.68 \% \\
(7.47)^{\circ} \\
(2.93) \\
\end{array}$ & $\begin{array}{l}-1.51 \% \\
(-3.10) \\
(-0.45) \\
\end{array}$ & $\begin{array}{l}-9.57 \% \\
(-9.69)^{* \cdots} \\
(-4.26) \\
\end{array}$ & $\begin{array}{l}-2.31 \% \\
(-2.39)^{* \cdots} \\
(-4.78) \\
\end{array}$ \\
\hline $\begin{array}{l}A D-1 \text { to } \\
A D\end{array}$ & $\begin{array}{c}0.51 \\
(0.31)^{*} \\
(2.32) \\
\end{array}$ & $\begin{array}{c}3.88 \\
(2.13)^{\cdots \cdots *} \\
(3.66) \\
\end{array}$ & $\begin{array}{l}2.21 \\
(2.13)^{\cdots \cdots} \\
(2.99)\end{array}$ & $\begin{array}{r}0.85 \\
(0.06) \\
(1.37) \\
\end{array}$ & $\begin{array}{c}-0.21 \\
(-0.02) \\
(-0.33) \\
\end{array}$ & $\begin{array}{c}0.83 \\
(0.51)^{\cdots \cdots} \\
(6.33)\end{array}$ \\
\hline $\begin{array}{l}A D+1 \text { to } \\
A D+1\end{array}$ & $\begin{array}{c}0.45 \\
(0.34) \\
(1.73) \\
\end{array}$ & $\begin{array}{c}3.13 \\
(1.51)^{* *} \\
(2.39) \\
\end{array}$ & $\begin{array}{l}2.02 \\
(2.11)^{* *} \\
(2.34) \\
\end{array}$ & $\begin{array}{c}0.64 \\
(1.48) \\
(0.95) \\
\end{array}$ & $\begin{array}{c}0.07 \\
(-0.30) \\
(0.09) \\
\end{array}$ & $\begin{array}{l}1.05 \\
(0.72)^{n \cdots *} \\
(6.99) \\
\end{array}$ \\
\hline $\begin{array}{l}A D+1 \text { to } \\
I D-1\end{array}$ & $\begin{array}{c}0.33 \\
(0.30) \\
(0.56) \\
\end{array}$ & $\begin{array}{r}1.32 \\
(-0.58) \\
(0.78) \\
\end{array}$ & $\begin{array}{l}-5.58 \\
(-6.81)^{*} \\
(-1.34)\end{array}$ & $\begin{array}{c}0.83 \\
(-0.19) \\
(0.73) \\
\end{array}$ & $\begin{array}{c}1.61 \\
(0.50) \\
(1.17) \\
\end{array}$ & $\begin{array}{l}2.79 \\
(1.15)^{\ldots .} \\
(6.67) \\
\end{array}$ \\
\hline ID - 1 to ID & $\begin{array}{l}-0.62 \\
(-0.82)^{* \cdots} \\
(-2.87)\end{array}$ & $\begin{array}{c}-0.12 \\
(-0.27) \\
(-0.22) \\
\end{array}$ & $\begin{array}{c}-0.28 \\
(0.22) \\
(-0.35) \\
\end{array}$ & $\begin{array}{c}0.59 \\
(1.11) \\
(0.85) \\
\end{array}$ & $\begin{array}{c}0.93 \\
(0.28) \\
(1.54) \\
\end{array}$ & $\begin{array}{c}0.21 \\
(0.00) \\
(1.76) \\
\end{array}$ \\
\hline $\begin{array}{l}\text { ID }-1 \text { to ID } \\
+1\end{array}$ & $\begin{array}{l}-1.01 \\
(-1.36)^{n} \\
(-3.82)\end{array}$ & $\begin{array}{l}-0.48 \\
(-0.85) \\
(-0.82) \\
\end{array}$ & $\begin{array}{c}0.70 \\
(0.55) \\
(0.69) \\
\end{array}$ & $\begin{array}{c}0.89 \\
(1.23) \\
(1.29) \\
\end{array}$ & $\begin{array}{l}1.26 \\
(0.58)^{*} \\
(1.95) \\
\end{array}$ & $\begin{array}{c}0.42 \\
(0.04) \\
(2.88) \\
\end{array}$ \\
\hline $\begin{array}{l}\text { Sum of } \\
A D-1 \text { to } \\
A D+1 \\
\text { and ID -1 } \\
\text { to ID +1 }\end{array}$ & $\begin{array}{l}-0.55 \\
(-0.88)^{*} \\
(-1.52)\end{array}$ & $\begin{array}{l}2.65 \\
(2.06)^{* *} \\
(1.96)\end{array}$ & $\begin{array}{l}2.72 \\
(5.17)^{* \cdots *} \\
(1.92)\end{array}$ & $\begin{array}{c}1.53 \\
(1.23) \\
(1.45)\end{array}$ & $\begin{array}{c}1.34 \\
(1.36) \\
(1.45)\end{array}$ & $\begin{array}{l}1.47 \\
(0.96)^{n \cdots} \\
(7.05)\end{array}$ \\
\hline
\end{tabular}




\begin{tabular}{|c|c|c|c|c|c|c|}
\hline \multirow[t]{3}{*}{ Interval } & \multicolumn{6}{|c|}{ Type of issue } \\
\hline & \multicolumn{3}{|c|}{ Common stock } & \multirow{2}{*}{$\begin{array}{c}\begin{array}{c}\text { Straight } \\
\text { debt }\end{array} \\
\begin{array}{c}\text { Public } \\
\text { offering } \\
(13)\end{array}\end{array}$} & \multirow{2}{*}{$\begin{array}{c}\text { Warrant } \\
\text { bond }\end{array}$} & \multirow{2}{*}{$\begin{array}{c}\text { Conver- } \\
\text { tible } \\
\text { bond }\end{array}$} \\
\hline & $\begin{array}{l}\text { Public } \\
\text { offering } \\
\text { (185) }\end{array}$ & $\begin{array}{c}\text { Private } \\
\text { offering } \\
(69)\end{array}$ & $\begin{array}{c}\text { Rights } \\
\text { offening } \\
(28)\end{array}$ & & & \\
\hline $\begin{array}{l}A D-1 \text { to } \\
I D+1\end{array}$ & $\begin{array}{c}-0.19 \\
(-0.80) \\
(-0.32) \\
\end{array}$ & $\begin{array}{c}4.70 \\
(2.07) \\
(2.10) \\
\end{array}$ & $\begin{array}{c}-2.54 \\
(-2.61) \\
(-0.61) \\
\end{array}$ & $\begin{array}{c}2.29 \\
(2.00)^{*} \\
(1.75) \\
\end{array}$ & $\begin{array}{c}2.13 \\
(0.14) \\
(1.45) \\
\end{array}$ & $\begin{array}{l}3.80 \\
(2.51)^{\circ+\infty} \\
(8.70)\end{array}$ \\
\hline $\begin{array}{l}10+1 \text { to } \\
10+20\end{array}$ & $\begin{array}{l}-0.86 \\
(-2.25)^{\star \ldots *} \\
(-1.35) \\
\end{array}$ & $\begin{array}{c}-0.52 \\
(-1.94) \\
(-0.35) \\
\end{array}$ & $\begin{array}{c}0.10 \\
(0.76) \\
(0.07) \\
\end{array}$ & $\begin{array}{c}1.15 \\
(0.85) \\
(0.88) \\
\end{array}$ & $\begin{array}{l}-1.62 \\
(-0.28) \\
(-0.99) \\
\end{array}$ & $\begin{array}{l}-1.21 \\
(-1.70)^{* \star *} \\
(-3.66)\end{array}$ \\
\hline $\begin{array}{l}A D-60 \text { to } \\
I D+20\end{array}$ & $\begin{array}{l}-1.35 \\
(-1.51)^{*} \\
(-1.05)\end{array}$ & $\begin{array}{l}16.39 \\
(4.02)^{\ldots . .} \\
(3.57)\end{array}$ & $\begin{array}{c}7.27 \\
(6.46) \\
(1.51)\end{array}$ & $\begin{array}{l}1.63 \\
(1.78) \\
(0.48)\end{array}$ & $\begin{array}{l}-9.39 \\
(-9.76)^{n * *} \\
(-3.27)\end{array}$ & $\begin{array}{r}0.06 \\
(-1.07) \\
(0.09)\end{array}$ \\
\hline
\end{tabular}

but small, $0.45 \%$ with a t-statistic of 1.73 . The median is $0.34 \%$, and the sign-rank test statistic is not significant. The results are slightly stronger for the two-day window which includes the announcement day and the day before. During the 19 days preceding the announcement, there are nine negative abnormal retums and 10 positive abnormal retums. Only one of these abnormal retums is significantly different from zero, namely day -19 , which is $-0.22 \%$ with a t-statistic of 1.74. This evidence indicates that our announcement date is meaningful. Day -1 , with an abnormal return of $0.41 \%$, has the highest abnormal return in absolute value for days -20 to 0 and the highest t-statistic. None of the 10 days following the announcement have a significant abnormal return. On the issuance day, the abnormal retum is negative. Its mean, median and t-statistic are all greater in absolute value thian the announcement day abnormal retum. For the 10 days preceding the issue day, one abnormal retum is significantly positive and two are significantly negative. The day after the issue is significantly negative, but none of the next nine 
days are significantly different from zero. Seven of these next nine days have a positive abnormal relum, though. Table 3 shows that the cumulative abnormal retums from the day before the announcement to the day after the issue are insignificant. Further, after the issue, the cumulative relurns for the next 20 days are negative, but the mean is insignificant. Finally, retums from day 60 before the announcement to day +20 after the issue are insignificantly negative. Since the issue day abnormal retum is significant, we provide a measure of the total abnormal return associated with the announcement and issue dates. To get this measure, we add up the abnormal relurn for the three days surrounding the announcement date and the three days surrounding the issue date. For equity issues, the mean of this total effect measure is insignificantly negative; the median is also negative and the sign-rank test is significant at the 0.05 level.

2. Private equity issues. Here, the effect is largely similar to what is found in the U.S. ${ }^{10}$ There is a large significant effecl for the three days surrounding the announcement day. The stock-price reaction is $3.13 \%$ with a t-statistic of 2.39 . There is no additional effect on issuance day. Private equity financings are shown here for the sake of completeness. They have been analyzed extensively by Kato and Schallheim (1993) over the period 1974 to 1988. They report an abnormal return of $4.98 \%$ on the board date and the day following the board date for their sample.

3. Rights offerings. The stock-price reaction to rights offerings is strongly positive on the announcement day. There is no further effect on issuance day. In contrast, the announcement day effect in the U.S. is close to zero."

4. Straight bond is sues. Neither the announcement nor the issue date abnormal retums

\footnotetext{
${ }^{10}$ See Wruck (1989).

"See Eckbo and Masulis (1992).
} 
are statistically significant. Since there are so few issues, however, the average abnormal returns are not estimated precisely. It is interesting to note that the economic significance of the total abnormal relurns for straight bond issues is similar to the economic significance of the total abnormal returns for the warrant bond issues and the convertible bond issues discussed next. The total average abnormal retum is $1.53 \%$ with a t-statistic of 1.45 .

5. Warrant bond issues. We have 19 offerings, in contrast to the 368 offshore offerings in Kang et al. (1994). There is no significant stock-price reaction to the issue announcement, but a positive stock-price reaction to the issuance is found when the three days surrounding the issuance are considered. The total average abnormal retum is $1.34 \%$ with a $t$-statistic of 1.45 .

6. Convertible bond issues. The stock-price reaction to convertible bond issues is surprisingly similar to the reaction documented in Kang et al. (1994) for offshore warrant bonds. We find a significant positive reaction to the announcement of $1.05 \%$ for the three days surrounding the announcement. For the 19 days before the day preceding the announcement, there is one significant abnormal retum on day -9. On that day, there is an increase of $0.15 \%$ with a t-statistic of 1.70 . The day -9 abnormal retum is the largest for these 19 days. It is much smaller than the day 0 announcement retum of $0.77 \%$ which has a t-statistic of 7.20 . Following the announcement, all abnormal returns from day +1 to day +10 are positive except for day +2 . In addition, three of these abnormal returns are significantly positive. This positive drift is clear from the table. which shows that from day +1 after the announcement date to day -1 before the issuance date, the cumulative abnormal retum is $2.79 \%$ with a t-statistic of 6.67 . Kang et al. (1994) also find a positive drift after the announcement of offshore warrant bond issues. Over the three days surrounding issuance, the abnormal retum is significantly positive. There is some negative drift from days +1 after the issue to day +20 . Over these days, the cumulative abnormal return is $-1.21 \%$ with a $t$-statistic of -3.66 . The total effect measure is positive and significant. 


\section{Section 4. Interpretation of the results.}

In this section, we focus on public equity and convertible debt issues. It is clear from the evidence in section 3 that the average total effect of the announcements associated with public equity issues is not significantly different from zero and that the average total effect of the announcements associated with public convertible debt issues is significantly positive. In studies of Japanese corporate finance, it is tempting to focus first and foremost on differences in the organization of firms with respect to the U.S. However, there are also differences in how markets are organized and these differences may be important for our sample. Before focusing on the implications of the organization of firms for our results, we address first potential explanations for our results which have to do with the organization of markets, the regulation of corporate finance in Japan and the "bubble economy."

\subsection{Market organization effects.}

Our results have several puzzling aspects which appear inconsistent with the hypothesis that markets are working without impediments. We consider in tum the puzzles conceming equity issues and convertible debt issues.

a) Equity issues. For equity issues, there is a significant positive abnormal retum for the three days surrounding the announcement. This suggests that the market views an equity issue as a positive event. Since the issuance itself confirms that a positive event is taking place for sure, one would expect a slight positive retum. Instead, we observe a significant negative retum of $-1.01 \%$ on the three days surrounding the issue with a t-statistic of -3.82 .

Lease, Masulis and Page (1991) propose an explanation for the fall of $0.3 \%$ on the day of the issue for industrial firms in the U.S. They argue that there is an order-flow imbalance on that day because individuals who want to buy the stock use the secondary issue to do so, so that 
on the primary market there are more sell orders than buy orders and the recorded prices are more likely to be bid prices than ask prices. Since trading costs are substantially higher in Tokyo than in the U.S., the same explanation could be at work here. ${ }^{12}$ If this explanation is correct, one would expect prices to bounce back after the issue day. There is no evidence of prices rebounding. The median abnormal retum is never positive for the 10 days following the issue day. Although only three of the mean abnormal retums are negative in these 10 days, the highest tstatistic is 1.06 and the highest mean abnormal retum, $0.205 \%$, on day +5 is lower in absolute value than the lowest mean abnormal retum, $-0.226 \%$, on day +9 . Finally, for the 20 days following the issue announcement, both the average abnormal retum and the median are negative. Though the t-statistic is insignificant, the sign-rank test statistic is significant at the 0.01 level. Of course, it could be the case that there is a negative drift after the offering that is partially offset by reversals. In regressions not reported here, we regressed the three-day issue abnormal return on the $\log$ of the market value of equity and the log of share price. Neither variable has a significant coefficient.

An altemative explanation could be that, rather than the price at the end of the issue day being abnormally low, the price the day before is abnormally high because of price support. In Japan, the offering day is the day when those who subscribed pay for the shares they bought. Hence, there is no reason to support the share price after the offering day. Underwriters are allowed to support the stock price between the day when the offering is priced and the offering

\footnotetext{
12 See Hamao and Hasbrouck (1992) for a description of the Tokyo market and estimates of the spread for the limit-order book. They investigate three stocks, all of which have a substantially higher capitalization than the average stock of a firm issuing equity in our sample. Their highest average spread is $1 \%$. It could be that the spread for the stocks in our sample exceeds $1 \%$, so that the negative abnormal retum on issue day would be comparable in its relation to the spread with the negative abnormal retum on issue day in the U.S.
} 
day. This period normally corresponds to the ten days before the offering day. ${ }^{13}$ Although price support or ramping seems to be a plausible explanation for the pattem of stock retums we observe, we had no success in finding traces of price support in the data. In our investigation, we focused on two samples of raw retums. The first sample (pre-sample) includes the raw retums for the ten days before the issue for each firm. The second sample (post-sample) inciudes the raw retums for the ten days starting thirty days after equity issues take place for each firm. The pre-sample has 1766 retums and the post sample 1827 . The pre-sample has a mean retum of $0.068 \%$ in contrast to $0.147 \%$ for the post-sample; the variance of the retums in the pre-sample is slightly lower than in the post-sample (4.76\% versus $5.55 \%)$ and the skewness is slightly higher $(0.92$ versus 0.80$)$. At best, the vaniance and skewness results indicate faint evidence of price support. However, this evidence becomes even weaker when one looks at the proportion of negative retums. In the pre-sample, $33.24 \%$ of the retums are below $-0.6 \%$ compared to $36.45 \%$ in the post-sample. If we focus on retums lower than $-3 \%$, we find that $5.78 \%$ of the beforesample are below $-3 \%$ in comparison with $6.13 \%$ of the retums in the post sample. We tried to relate the offering day abnormal retum to the number of days in the previous ten days the firm experienced a negative stock return in excess of one standard deviation of the firm's return. If a firm's stock price benefits from price support, one would see few such large negative returns but one would expect a sharp drop on the offening day. Therefore, it is likely that there is a positive relation between the number of large negative retums and the offering day abnormal retums. Instead, we found a negative insignificant relation.

b) Convertible debt issues. The announcement effect for convertible debt is positive and significant. The issue day announcement effect is also positive and significant, but much smaller. This is consistent with market efficiency if there is some probability that the issue will not take

\footnotetext{
${ }^{13}$ See Hanaeda (1993).
} 
place and the stock market reacts negatively to the news that the issue will not take place. What seems harder to explain is the existence of positive abnormal retums from the time of the issue announcement to the day before the issue. We find a cumulative abnormal retum of $2.79 \%$ with a t-statistic of 6.67 . This result suggests that a trading strategy of investing in the stock when the firm announces a convertible issue and selling the stock immediately before the issue date has a positive abnormal retum which exceeds potential transactions costs. One concem is that these trading profits could reflect the use of an inappropriate benchmark for retums computed over long periods of time. However, although we do not report the results in a table, we investigated whether these cumulative abnormal retums depend on firm size by splitting our sample of firms into large and small firms. We found that the cumulative abnormal retum from the day after the announcement to the day before the issue is $2.67 \%$ for the large firms with a median of $1.29 \%$ and is $2.90 \%$ for the small firms with a median of $1.06 \%$. Neither the mean nor the median difference is significant. It therefore seems unlikely that these cumulative abnormal retums are due to a misspecified benchmark.

The evidence suggests that the positive abnormal retums for convertible bond issues are more convincing than for equity issues. In either case, though, there is no evidence of a price drop of the magnitude observed for U.S. firms.

\subsection{Deregulation effects.}

In the 1980s, there was considerable deregulation in Japan. Before the 1980s, financing through domestic bond issues was extremely difficult for Japanese companies. ${ }^{14}$ First, unsecured issues were not allowed. Second, firms wishing to issue secured bonds could only do so if they

\footnotetext{
${ }^{14}$ See Hoshi, Kashyap and Scharfstein (1993) and Niimi (1992a,b) for discussions of the evolution of the Japanese bond market and of the evolution of the eligibility criteria for bond issuance.
} 
satisfied restrictive balance sheet conditions. Qualifying firms could issue only at specified times determined both by a queuing system and the practice of only issuing bonds at the end of the month. The choice of maturity for bonds was restricted. Lead managers were assigned to firms on a rotating basis to insure a balance of underwriting income among the Big four securities firms. Finally, interest rates on public bonds were regulated.

In 1979, Sears Roebuck made the first unsecured foreign bond issue on the Japanese market. Immediately following that issue, a regulatory standard for issuing unsecured bonds was adopted. It was so stringent that, until January 1983, only Toyota Motors and Matsushita Electric were allowed to issue domestic unsecured bonds. In January 1983, nine additional firms were allowed to issue unsecured straight debt and 23 more firms were allowed to issue unsecured convertible debt. The standards were progressively relaxed, so that by 1987, 180 firms were allowed to issue unsecured straight debt and 330 firms were allowed to issue unsecured convertible debt. A revision to the Commercial Code in April 1991 made the issuing standards less of an obstacle for most firms.

Changes in eligibility requirements to issue debt and equity-linked debt could explain positive abnormal returns. To see this, suppose that long-term shareholders allow firms to access capital markets, after they become eligible, only if their prospects are good enough that close monitoring of their actions through banks is no longer necessary. ${ }^{15}$ In this case, the first issue after a firm becomes eligible would convey information to the markets that a firm has good prospects. Hence, a first issue could reveal different information for Japanese firms during this sample period than for American firms because Japanese firms were allowed, for the first time,

${ }^{15}$ Hoshi, Kashyap and Scharfstein (1993) provide a model where the best firms raise funds on public markets because they do not benefit from close monitoring as much as other firms. They provide some empirical support of their model by investigating how reliance on bank loans changed across firms during the 1980s in Japan. 
to choose the amount of public debt in their capital structure.

Table 4 provides evidence on abnormal retums for firms which already have convertible debt and firms for which the convertible debt issue appears to be the first one. The stock-price reaction is significant for both groups of issues, but the stock-price reaction to a second issue is significantly smaller than the stock-price reaction to a first issue. There is therefore no evidence that firms which are not constrained by eligibility requirements entering the sample have stockprice reactions more comparable to those of American firms. Some convertible issues are secured, but most are not. Since it was easier to issue a convertible secured issue, it may be that looking at the whole sample obscures the effects of deregulation. We found 47 secured convertible issues and 385 unsecured convertible issues; for 129 issues, we could not determine whether the issue is secured or not. The average abnormal retums for secured and unsecured convertibles are $0.79 \%$ and $0.75 \%$, respectively. The average abnormal retum for a firm's first unsecured issue ( 82 issues) is $1.10 \%$ versus $0.65 \%$ for other issues. The difference is not statistically significant.

Another way to look at the role of deregulation is to investigate the relation between a firm's credit rating and the stock-price reaction to a convertible issue. Firms with a high rating are less likely to be affected by deregulation. Table 4 separates firms between those with a rating of $A, A A$ and $A A A$ on the one hand and those with a rating of $B, B B$, and $B B B$ on the other hand. The ratings are collected from the Nihon Kelzal Shinbun. The firms with a low rating have significantly higher stock-price reactions, but the stock-price reactions are positive for both groups of firms.

If deregulation explains our results, it should be the case that stock-price reactions become similar to the stock-price reactions of American firms in the later years in the sample. In table 5, we provide estimates of stock-price reactions year by year for equity issues and for 


\begin{tabular}{|c|c|c|c|}
\hline \multicolumn{4}{|c|}{ 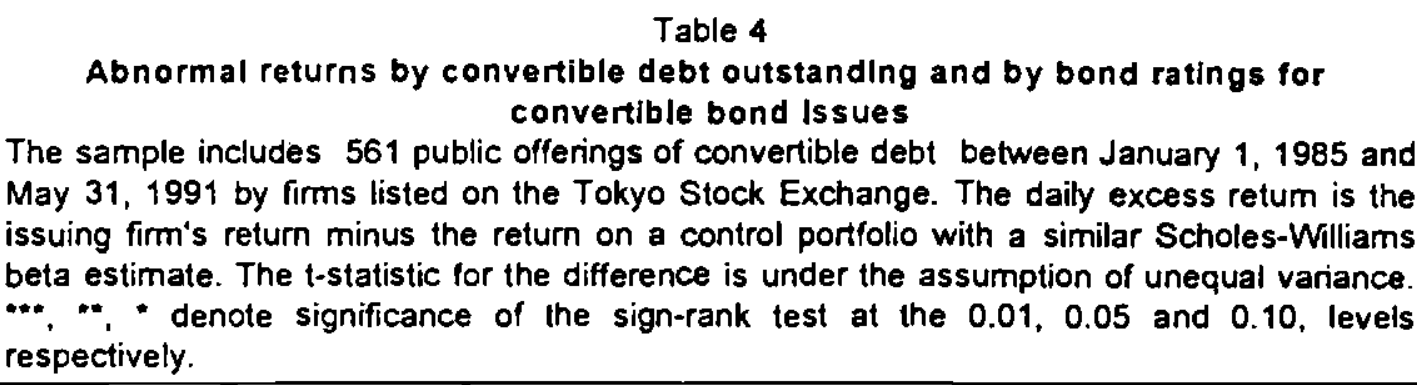 } \\
\hline Issue & $\begin{array}{l}\text { Number of } \\
\text { observations }\end{array}$ & $\begin{array}{c}\text { Average stock-price reaction } \\
\text { (Median) }\end{array}$ & $\begin{array}{c}\text { t-statistic } \\
\text { (Wilcoxon-z) }\end{array}$ \\
\hline \multicolumn{4}{|c|}{ A. Convertible debt outstanding. } \\
\hline First issue & 190 & $\begin{array}{c}1.76 \\
(1.50)^{\cdots * *}\end{array}$ & 6.66 \\
\hline $\begin{array}{l}\text { Issues by } \\
\text { firms with } \\
\text { convertible } \\
\text { debt out- } \\
\text { standing }\end{array}$ & 371 & $\begin{array}{l}0.68 \\
(0.37)^{* \cdots}\end{array}$ & 3.82 \\
\hline Difference & & $\begin{array}{c}1.08 \\
(1.13) \\
\end{array}$ & $\begin{array}{c}3.37 \\
(3.72) \\
\end{array}$ \\
\hline \multicolumn{4}{|c|}{ 8. Rating differences. } \\
\hline $\begin{array}{l}\text { Rating of } A \text {, } \\
\text { AA or AAA }\end{array}$ & 304 & $\begin{array}{c}0.62 \\
(0.35)^{* *}\end{array}$ & 3.07 \\
\hline $\begin{array}{l}\text { Rating of } \mathrm{B} \text {, } \\
\mathrm{BB} \text { or } \mathrm{BB8}\end{array}$ & 253 & $\begin{array}{c}1.54 \\
(1.21)^{* * *}\end{array}$ & 6.95 \\
\hline Difference & & $\begin{array}{l}-0.92 \\
(-0.86)\end{array}$ & $\begin{array}{l}-3.10 \\
(-3.67)\end{array}$ \\
\hline
\end{tabular}


convertible debt issues. For public equity issues, it appears that two years have much higher abnormal returns, namely 1985 and $1987 .{ }^{16}$ For each of these two years, the average stock-price reaction is more than three times higher than the next highest average stock-price reaction. We recomputed the average stock-price reaction for equity issues without 1985 and 1987. The 3-day announcement abnormal retum without these two years is $0.24 \%$ with a t-statistic of 0.86 . This evidence suggests the conclusion that the positive stock-price reaction to the announcement of equity issues for Japanese firms is unlikely to be a permanent feature of Japanese corporate finance.

\section{3. "Bubble economy" effects.}

We now briefly consider the effect of the "bubble economy" on the stock-price reaction. The dramatic increase in the Nikkei 225 index stopped at the end of 1989. If we split the sample between issues before 1990 and issues in 1990 and 1991, the stock-price reaction to the 33 issues in 1990 and 1991 is $-0.38 \%$ with a t-statistic of -0.61 , whereas the stock-price reaction to the 152 issues before 1990 is $0.64 \%$ with a t-statistic of 2.21 . The difference between these two samples is an economically significant $1.02 \%$ with a t-statistic of 1.47 . This provides further evidence that the significant positive abnormal retums for equity issues announcement are limited to a subset of our sample. It provides only limited evidence about the effect of the "bubble economy" because all but five of the issues in our sample for 1990 and 1991 are in January and February 1990.

No year seems to be particularly influential for the stock-price reaction to convertible bond issues. In particular. four years have an average announcement abnormal retum in excess of $1 \%$

\footnotetext{
${ }^{18}$ These two years constitute half of the sample of announcements for the 1980 s used by Kato and Schallheim (1992) who find an average abnormal retum of $0.76 \%$ with a t-statistic of 2.14 for the Board date and the following day for a sample from 1984 to March 1988.
} 


\begin{tabular}{|c|c|c|c|c|}
\hline \multicolumn{5}{|c|}{$\begin{array}{l}\text { Table } 5 \\
\text { Abnormal returns by year for equity and convertible issues } \\
\text { The sample inctudes } 185 \text { public equity offerings and } 561 \text { public convertible debt offerings } \\
\text { between January } 1,1985 \text { and May } 31,1991 \text { by firms listed on the Tokyo Stock Exchange. } \\
\text { The daily excess return is the issuing firm's retum minus the retum on a control portfolio } \\
\text { with a similar Scholes-Williams beta estimate. AD denotes the day the issue is announced } \\
\text { in the Nihon Keizai Shinbun and ID denotes the day of issuance. Medians, l-statistics and } \\
\text { the sample size are in parentheses. " *", and *** indicate significance of the sign-rank test } \\
\text { at the } 0.10,0.05 \text {, and } 0.01 \text { levels, respectively. }\end{array}$} \\
\hline \multirow[t]{2}{*}{ Year } & \multicolumn{2}{|c|}{ Public equity issues } & \multicolumn{2}{|c|}{ Public convertible issues } \\
\hline & $\begin{array}{l}A D-1 \text { to } \\
A D+1\end{array}$ & $\begin{array}{l}\text { ID }-1 \text { to } \\
\text { ID }+1\end{array}$ & $\begin{array}{c}A D-1 \text { to } \\
A D+1\end{array}$ & $\begin{array}{l}\text { ID - } 1 \text { 10 } \\
\text { ID + }\end{array}$ \\
\hline 1985 & $\begin{array}{l}1.75 \\
(1.95) \\
(1.18) \\
(9)\end{array}$ & $\begin{array}{l}-0.88 \\
(-0.83) \\
(-0.79) \\
(9)\end{array}$ & $\begin{array}{c}1.11 \\
(0.06)^{\circ} \\
(2.43) \\
(70)\end{array}$ & $\begin{array}{c}0.50 \\
(0.07) \\
(1.26) \\
(70)\end{array}$ \\
\hline 1986 & $\begin{array}{c}-0.23 \\
(1.38) \\
(-0.16) \\
(9) \\
\end{array}$ & $\begin{array}{l}0.40 \\
(-0.17) \\
(0.26) \\
(9) \\
\end{array}$ & $\begin{array}{c}0.80 \\
(0.52)^{*} \\
(2.25) \\
(73)\end{array}$ & $\begin{array}{c}1.56 \\
(0.78)^{* \cdots *} \\
(3.28) \\
(73)\end{array}$ \\
\hline 1987 & $\begin{array}{c}1.64 \\
(2.48) \\
(1.77) \\
(19) \\
\end{array}$ & $\begin{array}{l}-0.24 \\
(-0.96) \\
(-0.26) \\
(19) \\
\end{array}$ & $\begin{array}{c}1.31 \\
(1.23)^{\cdots \cdots} \\
(3.93) \\
(122)\end{array}$ & $\begin{array}{c}0.73 \\
(0.43)^{*} \\
(2.16) \\
(122)\end{array}$ \\
\hline 1988 & $\begin{array}{c}0.23 \\
(-0.29) \\
(0.38) \\
(33) \\
\end{array}$ & $\begin{array}{l}-2.60 \\
(-2.66)^{* *} \\
(-4.36) \\
(33)\end{array}$ & $\begin{array}{c}1.32 \\
(0.80)^{* \ldots *} \\
(3.48) \\
(117)\end{array}$ & $\begin{array}{c}0.17 \\
(0.04) \\
(0.59) \\
(117) \\
\end{array}$ \\
\hline 1989 & $\begin{array}{c}0.54 \\
(0.14) \\
(1.51) \\
(82) \\
\end{array}$ & $\begin{array}{l}-0.95 \\
(-1.54)^{* \cdots} \\
(-2.42) \\
(82)\end{array}$ & $\begin{array}{l}0.69 \\
(0.31)^{\circ *} \\
(2.50) \\
(124)\end{array}$ & $\begin{array}{l}-0.15 \\
(-0.68) \\
(-0.54) \\
(124)\end{array}$ \\
\hline 1990 & $\begin{array}{l}-0.25 \\
(-0.17) \\
(-0.41) \\
(30)\end{array}$ & $\begin{array}{l}-0.35 \\
(-0.82) \\
(-0.60) \\
(30)\end{array}$ & $\begin{array}{l}0.80 \\
(0.61) \\
(1.47) \\
(42)\end{array}$ & $\begin{array}{l}-0.10 \\
(0.10) \\
(-0.23) \\
(42)\end{array}$ \\
\hline 1991 & $\begin{array}{l}-1.76 \\
(-2.25) \\
(-0.44) \\
(3)\end{array}$ & $\begin{array}{l}-1.22 \\
(-1.42) \\
(-1.43) \\
(3)\end{array}$ & $\begin{array}{c}1.44 \\
(1.71)^{*} \\
(2.07) \\
(13)\end{array}$ & $\begin{array}{c}0.13 \\
(-1.04) \\
(0.10) \\
(13)\end{array}$ \\
\hline
\end{tabular}


with a t-statistic in excess of 2. For convertible debt issues, the post-bull market 1991 sample shows the highest average abnormal retum and the highest median in our sample. The mean abnormal return for issues before 1990 is $1.06 \%$ with a t-statistic of 6.65 in contrast to $0.96 \%$ with a t-statistic of 2.13 for issues in 1990 and 1991. The difference between these two subsamples is not significant at the 0.10 level.

\subsection{The role of differences in the organization of firms.}

It is often argued that Japan and the U.S. differ fundamentally in that Japanese managers have long horizons and U.S. managers have short horizons. One possible explanation for this difference, if it truly exists, is that long-term shareholders play an important role in Japanese firms. These shareholders, however, have a complex relationship with the firm in that they hold shares, hold debt, and conduct business transactions with it. As argued in Kang et al. (1994), it may well be that the best analogy for such investors is Admati and Pfleiderer's (1994) fixed fraction investors. If the controlling investors hold a constant fraction of all payouts from the firm, then new issues do not convey information about the mispricing of existing securities and the arguments of Myers and Majluf (1984) for why share prices fall following issues of risky securities do not apply.

If Japanese managers pursue different goals than American managers, in the sense that they do not care as much about wealth redistribution resulting from the sale of mispriced securities and are unwilling to sacrifice positive NPV projects to avoid such wealth redistribution. then they are less likely to issue following periods of positive abnormal retums for their securities than American managers. In the U.S., firms issue stock following periods of positive abnormal 
retums. ${ }^{17}$ The explanation for this phenomenon advanced by Lucas and McDonald (1990) is that the stock is least likely to be underpriced following a period when it has done extremely well. If Japanese firms behave differently, one would not expect to observe this phenomenon. Table 6 shows that Japanese firms do not issue equity or convertible bonds following significant positive excess returns. In fact, they seem to issue convertible debt following periods of significant negative excess returns. Further, there is no significant relation between announcement abnormal returns and abnormal retums preceding the announcement. These results hold equally if we use raw retums instead of abnormal retums. Hence, the adverse selection explanation for the abnormal returns associated with new issues does not appear to hold for Japanese firms.

An alternative way of investigating the role of institutional arrangements is to compare the abnormal retums for firms where management is more likely to behave like the management of American firms. Table 7 provides evidence on this issue. First, we divide the sample between firms that belong to a horizontal Keiretsu and those that do not. We find some difference between the two groups for equity issues. Namely, whereas there is no difference on issue day, the Keiretsu firms are the only ones with a significant abnormal return on the announcement day. Unfortunately, the difference between the two groups of firms is not significant. This result is similar to the one found in Kang et al. (1994) for offshore warrant bond issues. In contrast, when we look at convertible bond issues, there is no difference whatsoever between the two groups on the announcement date and the non-keiretsu firms have a significant abnormal retum on issue date but the Keiretsu firms do not.

As emphasized by Saxonhouse (1993), altemative Keirelsu classifications lead to very different lists of member firms. Consequently, the fact that Keiretsu membership is not very helpful

${ }^{17}$ See Asquith and Mullins (1986). Korajczyk, Lucas and McDonald (1990) provide a detailed analysis of the excess retums before an issue. 


\begin{tabular}{|c|c|c|}
\hline \multicolumn{3}{|c|}{ 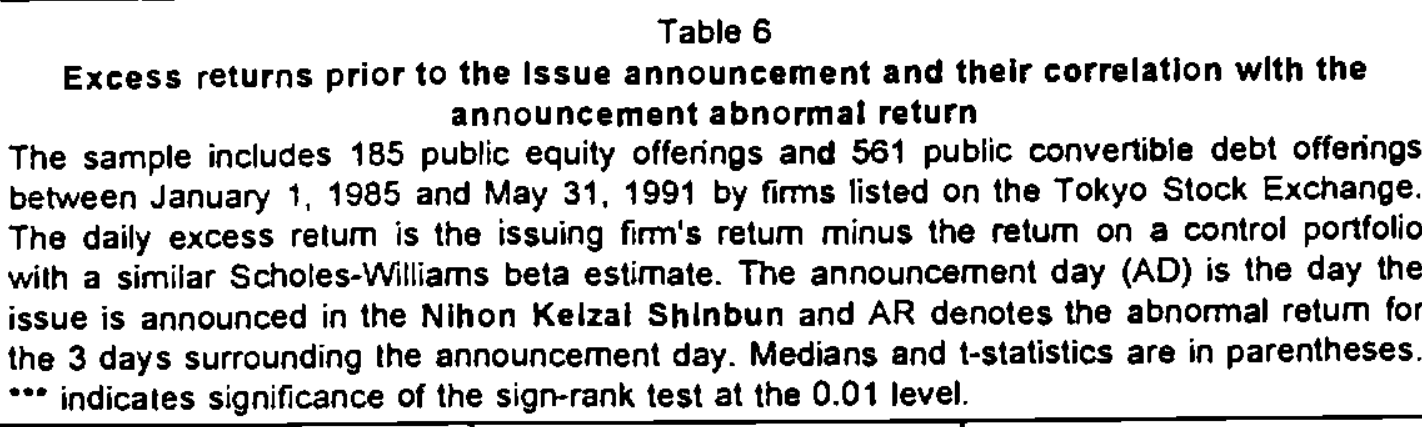 } \\
\hline & Public equity issues & Public convertible issues \\
\hline $\begin{array}{l}\text { A. Stock return for } \\
A D-220 \text { to } A D-20\end{array}$ & $\begin{array}{l}31.39 \% \\
(26.95)^{\circ *} \\
(12.03)\end{array}$ & $\begin{array}{l}24.38 \% \\
(19.76)^{\circ *} \\
(18.15) \\
\end{array}$ \\
\hline $\begin{array}{l}\text { B. Portfolio return for } \\
A D-220 \text { to } A D-20\end{array}$ & $\begin{array}{l}30.75 \\
(32.34)^{\circ \ldots \star} \\
(27.28)\end{array}$ & $\begin{array}{l}29.30 \\
(29.51)^{\star \ldots * t} \\
(39.34) \\
\end{array}$ \\
\hline C. Excess retum & $\begin{array}{r}0.36 \\
(-3.81) \\
(0.21) \\
\end{array}$ & $\begin{array}{l}-3.63 \\
(-7.13)^{*} \\
(-3.97) \\
\end{array}$ \\
\hline $\begin{array}{l}\text { Correlation belween } \\
\text { AR and } A \text { ( } p \text {-value) }\end{array}$ & $\begin{array}{l}-0.07 \\
(0.36)\end{array}$ & $\begin{array}{c}0.02 \\
(0.65)\end{array}$ \\
\hline $\begin{array}{l}\text { Correlation between } A R \text { and } \\
B \text { (p-value) }\end{array}$ & $\begin{array}{l}-0.04 \\
(0.55)\end{array}$ & $\begin{array}{l}-0.01 \\
(0.84) \\
\end{array}$ \\
\hline $\begin{array}{l}\text { Correlation between } A R \text { and } \\
C \text { (p-value) }\end{array}$ & $\begin{array}{l}-0.07 \\
(0.36)\end{array}$ & $\begin{array}{c}0.02 \\
(0.60)\end{array}$ \\
\hline
\end{tabular}


Table 7

Abnormal returns by Kelretsu membership, firm slze and bank loans

The sample includes 185 public equity offerings and 561 public convertible debt offerings between January 1, 1985 and May 31, 1991 by firms listed on the Tokyo Stock Exchange. The daily excess retum is the issuing firm's retum minus the retum on a control portfolio with a similar Scholes-Williams beta estimate. AD denotes the day when the issue is announced in the Nihon Keizal Shinbun and ID denotes the issuance day. Medians, tstatistics and the sample size are in parentheses. ${ }^{*},{ }^{*}$, and ${ }^{* *}$ indicate significance of the sign-rank test at the $0.10,0.05$, and 0.01 levels respectively.

\begin{tabular}{|c|c|c|c|}
\hline \multicolumn{2}{|c|}{ Public equity issues } & \multicolumn{2}{|c|}{ Public convertible issues } \\
\hline $\begin{array}{c}A D-1 \text { to } \\
A D+1\end{array}$ & $\begin{array}{c}I D-1 \text { to } \\
I D+1\end{array}$ & $\begin{array}{c}A D-1 \text { to } \\
A D+1\end{array}$ & $\begin{array}{c}\text { ID }-1 \text { to } \\
I D+1\end{array}$ \\
\hline
\end{tabular}

A. Firms that belong to a Keiretsus versus those that do not.

\begin{tabular}{|c|c|c|c|c|}
\hline Keiretsu firms & $\begin{array}{c}0.81 \\
(1.02)^{*} \\
(1.93) \\
(68)\end{array}$ & $\begin{array}{l}-1.11 \\
(-1.59)^{* \ldots *} \\
(-2.47) \\
(68)\end{array}$ & $\begin{array}{l}1.13 \\
(0.72)^{* \ldots *} \\
(5.07) \\
(208)\end{array}$ & $\begin{array}{c}0.26 \\
(-0.11) \\
(1.08) \\
(208)\end{array}$ \\
\hline Non-Keiretsu firms & $\begin{array}{c}0.25 \\
(-0.24) \\
(0.74) \\
(117) \\
\end{array}$ & $\begin{array}{l}-0.95 \\
(-1.06)^{* \cdots} \\
(-2.89) \\
(117)\end{array}$ & $\begin{array}{l}1.00 \\
(0.72)^{\cdots \cdots} \\
(5.03) \\
(353)\end{array}$ & $\begin{array}{l}0.52 \\
(0.14)^{* \bullet} \\
(2.81) \\
(353)\end{array}$ \\
\hline $\begin{array}{l}\text { Mean difference } \\
\text { Median difference } \\
\text { t-statistic } \\
\text { Wilcoxon-Z }\end{array}$ & $\begin{array}{l}-0.56 \\
(-1.26) \\
(-1.04) \\
(-0.92) \\
\end{array}$ & $\begin{array}{l}0.16 \\
(0.53) \\
(0.28) \\
(0.99) \\
\end{array}$ & $\begin{array}{l}-0.13 \\
(0.00) \\
(-0.42) \\
(-0.60)\end{array}$ & $\begin{array}{l}0.26 \\
(0.25) \\
(0.83) \\
(1.34)\end{array}$ \\
\hline \multicolumn{5}{|c|}{ B. Large firms versus small firms. } \\
\hline Large firms & $\begin{array}{l}-0.55 \\
(-1.12)^{*} \\
(-1.71) \\
(92)\end{array}$ & $\begin{array}{l}-0.67 \\
(-1.04)^{* * *} \\
(-1.93) \\
(92)\end{array}$ & $\begin{array}{c}0.46 \\
(0.13) \\
(2.22) \\
(281) \\
\end{array}$ & $\begin{array}{c}0.25 \\
(0.04) \\
(1.33) \\
(281) \\
\end{array}$ \\
\hline Small firms & $\begin{array}{l}1.45 \\
(1.45)^{* \ldots *} \\
(3.71) \\
(93)\end{array}$ & $\begin{array}{l}-1.34 \\
(-1.67)^{* \ldots *} \\
(-3.38) \\
(93)\end{array}$ & $\begin{array}{c}1.64 \\
(1.34)^{\cdots \cdots} \\
(7.73) \\
(280)\end{array}$ & $\begin{array}{c}0.60 \\
(0.08) \\
(2.63) \\
(280)\end{array}$ \\
\hline $\begin{array}{l}\text { Mean difference } \\
\text { Median difference } \\
\text { t-statistic } \\
\text { Wilcoxon-Z }\end{array}$ & $\begin{array}{l}2.00 \\
(2.57) \\
(3.94) \\
(4.07)\end{array}$ & $\begin{array}{l}-0.67 \\
(-0.63) \\
(-1.28) \\
(-1.27)\end{array}$ & $\begin{array}{l}1.18 \\
(1.21) \\
(4.01) \\
(4.66)\end{array}$ & $\begin{array}{l}0.35 \\
(0.04) \\
(1.18) \\
(0.47)\end{array}$ \\
\hline
\end{tabular}


C. FIms with bank loan financing versus firms with no bank loan financing, matching by the market value of equity and by the year of issue.

\begin{tabular}{|c|c|c|c|c|}
\hline Firms with no bank loans & $\begin{array}{l}-0.92 \\
(-1.28) \\
(-0.90) \\
(17)\end{array}$ & $\begin{array}{l}-0.47 \\
(-0.49) \\
(-0.49) \\
(17)\end{array}$ & $\begin{array}{c}1.06 \\
(0.59)^{*} \\
(2.23) \\
(66)\end{array}$ & $\begin{array}{l}0.45 \\
(0.59) \\
(1.16) \\
(66)\end{array}$ \\
\hline $\begin{array}{l}\text { Firms with bank loans } \\
\text { (matched by size and year) }\end{array}$ & $\begin{array}{l}1.60 \\
(2 . .48)^{*} \\
(1.93) \\
(17)\end{array}$ & $\begin{array}{l}-1.71 \\
(-1.93)^{* \cdots} \\
(-3.62) \\
(17)\end{array}$ & $\begin{array}{l}1.28 \\
(1.18)^{* 0 *} \\
(3.56) \\
(66)\end{array}$ & $\begin{array}{c}0.96 \\
(0.53) \\
(2.12) \\
(66)\end{array}$ \\
\hline $\begin{array}{l}\text { Mean difference } \\
\text { Median difference } \\
\text {-statistic } \\
\text { Wilcoxon-Z }\end{array}$ & $\begin{array}{l}-2.52 \\
(-3.76) \\
(-1.92) \\
{[-1.76]}\end{array}$ & $\begin{array}{l}1.24 \\
(1.44) \\
(1.15) \\
{[0.83]}\end{array}$ & $\begin{array}{l}-0.22 \\
(-0.59) \\
(-0.36) \\
{[-0.83]}\end{array}$ & $\begin{array}{l}-0.51 \\
(0.06) \\
(-0.86) \\
{[0.43]}\end{array}$ \\
\hline
\end{tabular}

in predicting abnormal retums may simply mean that our Keiretsu classification is not precise enough. This problem suggests an altemative approach to identify the firms that resembie American firms the most, namely the use of firm size. Large firms are less likely to be constrained in their actions by their shareholders or by a main bank. In particular, large firms are unlikely to have to rely mostly on bank borrowing for their financing. Panel $B$ of table 7 provides strong evidence that size matters. Large firms have a significant negative abnormal retum for the threeday window surrounding the announcement day in contrast to small firms which have a significant increase for equity issues. For convertible bond issues, the announcement effect is also significantly larger for small firms, but the announcement effect is positive for both sets of firms. On issue day, there is no significant difference.

An obvious concern with the size results is that they are subject to alternative interpretations. For instance, size might help understand the cross-sectional variation in abnormal retums because of microstructural effects or because size is related to the degree of information asymmetry about a firm. The argument that size proxies for microstructural effects is that small 
firms tend to have lower stock prices, so that the fixed part of transaction costs is more important for these firms relative to the stock price. We find that there is a significant relation between price and abnormal retum in regressions that do not control for size. However, when abnormal retums are regressed on size and price, price is never significant and size is always significant. Herice, the explanation for the role of size is not a mechanical microstructural explanation having to do with the stock price. We estimated similar regressions for the issue day retum and found no significant coefficient, indicating that this abnormal retum may not be related to microstructure effects either. In the U.S., it is often argued that informational asymmetries are greater for small firms than for large firms. In the context of the Myers and Majluf (1984) model, this would suggest a greater price drop for small firm equity issues than for large firm equity issues, which obviously is the opposite result from the one observed here. It could be, though, that equity issues have a positive effect and that issues by small firms are more unexpected than issues by large firms. This interpretation would be promising if the average abnormal retum for large firms was insignificantly different from zero; instead, it is significantly negative.

Even if large firms are more similar to U.S. firms, this may be because they have better access to capital markets rather than because of control considerations. One way to get a betler perspective on this issue is to focus on firms of similar size but different reliance on bank loans. Because these firms have similar size, their access to capital markets should be similar and if their abnormal returns differ, it most likely would be because the ones with bank loans are monitored by banks in contrast to the firms with no bank loans. In panel $\mathrm{C}$ of table 7 , we also compare announcement abnormal retums between firms in our sample with no bank loan financing and firms with loan financing by banks or other financial intermediaries (these two calegories of loans are aggregated in the accounting data reported by PACAP). Since bank loans became less important during our sample period (see Hoshi, Kashyap and Scharfstein (1993)), 
it is important to make sure that announcements by firms without bank loans are compared to contemporaneous announcements by firms with banks loans. The results reported in panel $\mathrm{C}$ of table 7 are striking. The firms with banks loans have significantly higher abnormal retums than the firms without banks loans for equity issues. The difference of $2.52 \%$ is not only statistically significant, but it is also economically large. It is puzzling, though, that firms with bank loans in this matched sample also have a large negative stock-price reaction on the offering day. Nevertheless, there is no significant difference on the offering day between the two samples. Although we do not report these results in the table, we also split the sample into two according to loans to total assets. Firms with loans to total assets above the sample median have a threeday abnormal retum associated with the announcement of equity issues of $1.16 \%$ that is significantly larger than the abnormal return of $-0.26 \%$ of the firms with loans to total assets below the sample median (at the 0.01 level). The loan component of a firm's capital structure is related to the announcement abnormal retum for equity issues, but not to the announcement abnormal return for convertible debt issues. There is no significant difference in panel $C$ of table 7 between convertible issuing firms that rely on bank loans and those that do not; in addition, there is also no significant difference when we compare abnormal retums for firms with loans to total assets above the sample median and below the sample median.

Table 8 presents estimates of multivariate regressions which use the three-day announcement abnormal return as the dependent variable. We present six regressions. The first two show that size is more important than price in explaining the cross-sectional variation of abnormal returns. The next two regressions provide some evidence that firms belonging to a horizontal Keiretsu have higher abnormal returns. The coefficient on the Keiretsu indicator variable is positive and significant at the 0.10 level for equity issues and it is positive, but insignificant, for convertible bond issues. 


\begin{tabular}{|c|c|c|c|c|c|c|}
\hline \multicolumn{7}{|c|}{$\begin{array}{l}\text { Table } 8 \\
\text { Multivariate regression of 3-day announcement abnormal returns on firm characte- } \\
\text { ristlcs }\end{array}$} \\
\hline \multirow{2}{*}{$\begin{array}{l}\text { Regres- } \\
\text { sion }\end{array}$} & \multicolumn{6}{|c|}{ Security issue } \\
\hline & 1. Equily & $\begin{array}{l}\text { 2. Conver- } \\
\text { tible }\end{array}$ & 3. Equity & $\begin{array}{l}\text { 4. Conver- } \\
\text { tible }\end{array}$ & 5. Equity. & $\begin{array}{l}\text { 6. Con- } \\
\text { vertible }\end{array}$ \\
\hline Constant & $\begin{array}{l}10.01 \\
(3.49)\end{array}$ & $\begin{array}{c}7.33 \\
(3.98)\end{array}$ & $\begin{array}{c}7.93 \\
(2.77)\end{array}$ & $\begin{array}{c}7.89 \\
(3.55)\end{array}$ & $\begin{array}{c}5.79 \\
(1.90)\end{array}$ & $\begin{array}{c}8.55 \\
(3.79)\end{array}$ \\
\hline $\log M V$ & $\begin{array}{c}-0.56 \\
(-2.70) \\
\end{array}$ & $\begin{array}{c}-0.52 \\
(-4.20)\end{array}$ & $\begin{array}{c}-0.73 \\
(-3.22)\end{array}$ & $\begin{array}{c}-0.57 \\
(-3.54)\end{array}$ & $\begin{array}{c}-0.53 \\
(-2.30)\end{array}$ & $\begin{array}{c}-0.55 \\
(-3.67)\end{array}$ \\
\hline Log Price & $\begin{array}{c}-0.48 \\
(-1.11)\end{array}$ & $\begin{array}{c}-0.01 \\
(-0.06)\end{array}$ & & & & \\
\hline $\begin{array}{l}\text { Amount/ } \\
M V\end{array}$ & & & $\begin{array}{c}0.54 \\
(0.12)\end{array}$ & $\begin{array}{c}-1.09 \\
(-0.33)\end{array}$ & $\begin{array}{l}-1.70 \\
(-0.37)\end{array}$ & $\begin{array}{l}-1.25 \\
(-0.37)\end{array}$ \\
\hline $\begin{array}{l}\text { Keiretsu } \\
\text { dummy }\end{array}$ & & & $\begin{array}{c}1.00 \\
(1.87)\end{array}$ & $\begin{array}{c}0.30 \\
(0.99)\end{array}$ & $\begin{array}{c}0.74 \\
(1.31)\end{array}$ & $\begin{array}{c}0.51 \\
(1.57)\end{array}$ \\
\hline PE & & & & & $\begin{array}{c}-0.02 \\
(-2.70)\end{array}$ & $\begin{array}{l}-0.00 \\
(-0.67)\end{array}$ \\
\hline DebUTA & & & & & $\begin{array}{c}1.79 \\
(0.98) \\
\end{array}$ & $\begin{array}{c}-1.10 \\
(-0.84)\end{array}$ \\
\hline Loans/TA & & & & & $\begin{array}{c}3.80 \\
(2.40)\end{array}$ & $\begin{array}{c}-2.04 \\
(-1.90)\end{array}$ \\
\hline $\begin{array}{l}\text { R-square } \\
\text { p-val. F- } \\
\text { test }\end{array}$ & $\begin{array}{r}0.07 \\
<0.01\end{array}$ & $\begin{array}{r}0.04 \\
<0.01\end{array}$ & $\begin{array}{r}0.09 \\
<0.01\end{array}$ & $\begin{array}{r}0.04 \\
<0.01\end{array}$ & $\begin{array}{r}0.11 \\
<0.01\end{array}$ & $\begin{array}{r}0.04 \\
<0.01\end{array}$ \\
\hline
\end{tabular}


Regressions 5 and 6 relate abnormal returns to several different variables that one might expect to be related to abnormal returns based on U.S. results and on the analysis conducted so far in this paper. Since past excess returns are not informative for the abnormal returns, we use the PE ratio. With the adverse selection model, one would expect $P E$ to have a negative effect on abnormal return for Japan because high PE firms would be more likely to issue, so their issues would be more anticipated. Similarly, one would expect highly levered firms to be more likely to issue if high leverage means that firms are farther away from their equilibrium capital structure. The PE ratio is negatively related to the abnormal return. The coefficient is significant at the 0.01 level for equity issues but is insignificant for convertible issues. We allow for a different relation between loans and abnormal returns and between the remainder of the firm's liabilities and abnormal returns. It turns out that the abnormal return for equity issues is positively related to loans normalized by total assets and is unrelated to the magnitude of other liabilities normalized by assets. With convertible debt issues, loans has a negative impact. However, this negative impact is suspect. Since PEs can take extremely high values, it makes sense to investigate whelher the regression results are affected by outliers. If we remove $5 \%$ of firms with highest and lowest PEs in each sample, the regression for equity abnormal retums is essentially unchanged, but loans $/ \mathrm{TA}$ is no longer significant in the convertible regression.

In regressions not reported here for the convertible debt sample, we also included a dummy vaniable for secured debt, the Gensaki rate, and a variable equal to the difference between the coupon rate and the Gensaki rate as proxy for the magnitude of the equity component of the convertible issue. The coefficients on secured debt and the Gensaki rate are never significant. In contrast, the coefficient on the difference between the coupon rate and the Gensaki rate has a positive coefficient and is always significant. This suggests that the stock price reaction increases as the equity component falls. Since coupon rates were fairly standardized, 
this result should be interpreted with caution.

The coefficient on PE raises the question of whether Japan is as different from the U.S. as argued so far. It could indicate that Japanese firms are as likely as U.S. firms to issue equity when their valuation is high, so that in both countries high valuation firms have abnormal retums close to zero. With this view, the past excess retums might simply be poor valuation measures for Japanese firms. It tums out that this impression is misleading and that PE does not play the role one would expect it to play if high PE firms are more likely to be overvalued and Japanese firms behave like U.S. firms. In table 9, we divide the sample into large and small firms and large and small PE firms. Within firm size classes, PE does not lead to significant differences. Within PE classes, size matters. Yet, for equity issues in panel $A$, the large firms with high PEs have significantly negative abnormal retums of $-0.91 \%$ with a t-statistic of -2.13 , indicating that these firms have announcement retums more similar to those of U.S. firms. At the same time, though, there is no evidence that issues by firms with high PEs are more anticipated within a firm size class: for both firm size classes, high PE firms have higher absolute value of abnormal retums. The results for convertible issues in panel $B$ of table 9 indicate that small firms with high PEs have higher abnormal retums. In contrast, large firms with high PEs have lower abnormal retums. Interestingly, the large firms with high PEs do not have significant positive abnormal retums.

Though PE does not lead to significant differences within size classes, it is puzzling that for sraall firms abnormal retums seem to positively related to PE whereas for large firms the opposite seems to be true. It tums out that this may be further evidence that large Japanese firms are more similar to U.S. firms. We estimated a regression of abnormal retums on a constant, PE, and PE times a dummy variable which takes value one if a firm has a market value of equity above the sample median. For equity issues, PE is insignificant and the regression coefficient on $P E$ is -0.004 with a t-statistic of -0.312 . In contrast, PE times the dummy variable has a 
Table 9

3-day announcement abnormal returns according to PE and firm size classes

The sample includes 185 public equity offerings and 561 public convertible debt offerings between January 1, 1985 and May 31, 1991 by firms listed on the Tokyo Stock Exchange.

The daily excess retum is the issuing firm's retum minus the retum on a control portiolio with a similar Scholes-Williams beta estimate. The announcement day is the day when the issue is announced in the Nihon Kelzal Shinbun. Large firms are firms with market value in excess of the median for firms issuing the same security. High PE firms are firms with a PE greater than the median for firms issuing the same security.* ** and ** denote significance of the sign-rank test at the $0.10,0.05$ and 0.01 levels, respectively.

\begin{tabular}{|c|c|c|c|}
\hline & $\begin{array}{l}\text { Small firms } \\
\text { (median) } \\
\{t \text {-statistic\} } \\
\# \text { of firms } \\
\end{array}$ & $\begin{array}{c}\text { Large firms } \\
\text { (median) } \\
\text { \{t-statistic\} } \\
\# \text { of firms } \\
\end{array}$ & $\begin{array}{c}\text { Difference } \\
\text { (median) } \\
\{\text { t-statistic\} } \\
\text { [Wilcoxon-z] }\end{array}$ \\
\hline \multicolumn{4}{|c|}{ Panel A. Equity issues. } \\
\hline Low PE firms & $\begin{array}{l}1.36 \% \\
(1.38)^{* \ldots} \\
\{2.71\} \\
47\end{array}$ & $\begin{array}{l}-0.20 \% \\
(-0.83) \\
\{-0.43\} \\
46 \\
\end{array}$ & $\begin{array}{l}1.56 \% \\
(2.21) \\
\{2.26\} \\
{[2.33]} \\
\end{array}$ \\
\hline High PE firms & $\begin{array}{l}1.53 \\
(1.84)^{* \ldots *} \\
\{2.54\} \\
46\end{array}$ & $\begin{array}{l}-0.91 \\
(-1.24)^{\circ *} \\
\{-2.13\} \\
46\end{array}$ & $\begin{array}{l}2.44 \\
(3.08) \\
\{3.30\} \\
{[3.43]} \\
\end{array}$ \\
\hline $\begin{array}{l}\text { Difference } \\
\text { (median) } \\
\text { (t-statistic) } \\
\text { (Wilcoxon-z) }\end{array}$ & $\begin{array}{l}-0.17 \\
(-0.46) \\
\{-0.21\} \\
{[-0.41]} \\
\end{array}$ & $\begin{array}{c}0.71 \\
(0.41) \\
\{1.10\} \\
{[0.93]} \\
\end{array}$ & \\
\hline \multicolumn{4}{|c|}{ Panel $\mathrm{B}$. Convertible issues } \\
\hline Low PE firms & $\begin{array}{c}1.40 \\
(1.09)^{\cdots \cdots} \\
\{4.48\} \\
140 \\
\end{array}$ & $\begin{array}{c}0.65 \\
(0.35)^{*} \\
\{2.31\} \\
141\end{array}$ & $\begin{array}{c}0.75 \\
(0.74) \\
\{1.80\} \\
{[1.81]} \\
\end{array}$ \\
\hline High PE firms & $\begin{array}{c}1.89 \\
(1.60)^{\star \cdots *} \\
\{6.56\} \\
140 \\
\end{array}$ & $\begin{array}{c}0.27 \\
(-0.04) \\
\{0.88\} \\
140 \\
\end{array}$ & $\begin{array}{l}1.62 \\
(1.64) \\
\{3.88\} \\
{[4.87]} \\
\end{array}$ \\
\hline $\begin{array}{l}\text { Difference } \\
\text { (median) } \\
\text { \{t-statistic\} } \\
\text { [Wilcoxon-z] }\end{array}$ & $\begin{array}{l}-0.49 \\
(-0.51) \\
\{-1.13\} \\
{[-1.17]}\end{array}$ & $\begin{array}{c}0.38 \\
(0.39) \\
\{0.92\} \\
{[1.42]}\end{array}$ & \\
\hline
\end{tabular}


regression coefficient of -0.02 with a t-statistic of -2.76 . Hence, if PE matters, it does so only for large firms. The regressions in table 8 therefore seem to contradict the results in table 9 because they do not allow for PE to be related differently to abnormal retums for large and small firms. Similar results hold for convertible issues, except there the coefficient of PE is 0.001 with a tstatistic of 1.35 .

\section{Section 5. Conclusion.}

Our main findings are as follows:

1. The average total abnormal retum for equity-linked debt issues by Japanese companies is unambiguously positive, whereas the average total abnormal retum for public equity issues is negative but insignificant. Hence, Japanese companies have stock-price reactions to security issues that are different from those of the American companies.

2. For Japanese companies, the announcement day retum is smaller in absolute value than the issue day retum for public equity issues, but not for convertible issues. The large issue day retum for public equity issues is puzzling in that it cannot be explained directly by microstructure considerations or price support.

3. Deregulation seems to explain part of the significant positive abnormal retum associated with convertible issues, but not all of it.

4. Large Japanese companies have lower abnormal retums and hence have abnormal returns which are closer to those experienced by American companies. In particular, the largest Japanese companies in the sample have a significant negative stock-price reaction to public equity issue announcements. There is also weak evidence that companies which do not belong to a horizontal keiretsu have lower abnormal retums and strong evidence that firms with less loans in their capital structure have lower abnormal retums than firms with more loans. 
5. In contrast to American companies, Japanese companies do not issue equity or equitylinked debt following a period of positive abnormal returns.

The evidence in this paper is supportive of the view that during our sample period Japanese managers issued securities with different objectives than American managers. In particular, they were not as concerned about mispricing of existing securities as American managers seem to be and consequently the stock market's reaction to issues of risky securities was not as negative as it typically is in the U.S. This is consistent with the view that Japanese managers care less about short-term shareholders than American managers. 


\section{References}

Admati, A.R., and P. Pfleiderer, 1994, Robust financial contracting and the role of venture capitalists, Joumal of Finance 49, 371-402.

Asquith, P., and D.W. Mullins, Jr., 1986, Equity issues and offering dilution, Joumal of Financial Economics 15, 31-60.

Campbell, J.Y., and Y. Hamao, 1993, Changing pattems of corporate financing and the main bank system in Japan, mimeo.

Dybvig, P.H., and J.F. Zender, 1991, Capital structure and dividend irrelevance with asymmetric information, The Review of Financial Studies 4, 201-220.

Eckbo, 8. E., and R.W. Masulis, 1992, Adverse selection and the rights offer paradox, Joumal of Financial Economics 32, 293-332.

French, K.R., and J.M. Poterba, 1991. Were Japanese stock prices too high?, Joumal of Financial Economics 29. 337-364.

Gerlach, M. L., 1992, Alliance capitalism: The social organization of Japanese business, University of Califomia Press, Berkeley and Los Angeles, Califomia.

Gilson, R.J., and M. Roe, 1993, Understanding the Japanese keiretsu: Overlaps between corporate governance and industrial organization, Yale Law Journal, 871-907.

Hanaeda, H., 1993, Seasoned equity issues in Japan, in Japanese Capital Markets, S. Takagi, ed., Basil Blackwell, Okford, UK, and Cambridge, US.

Hamao, Y., and J. Hasbrouck, 1992. Securities trading in the absence of dealers: Trades and quotes on the Tokyo stock exchange, unpublished working paper, New York University.

Hoshi, T., A. Kashyap, and D. Scharfstein, 1993. The choice between public and private debt: An analysis of post-deregulation corporate financing in Japan, mimeo.

Kang, J.-K., Y.-C. Kim, K.-J. Park, and R.M. Stulz, 1994, An analysis of the wealth effects of 
Japanese offshore dollar-denominated convertible and warrant bond issues, unpublished working paper, Ohio State University.

Kaplan, S.N., 1994, Top executive rewards and firm performance: A comparison of Japan and the U.S., Joumal of Political Economy, forthcoming.

Kato, K., and J.S. Schallheim, 1992, Public and private placements of seasoned equity issues in Japan, unpublished paper, University of Utah.

Kato, K., and J.S. Schallheim, 1993, Private equity financing in Japan and corporate grouping (keiretsu), Pacific-Basin Finance Journal 1, 287-307.

Kester, W.C., 1990, Govemance, contracting, and investment horizons: A look at Japan and Germany. The Continental Bank Joumal of Applied Corporate Finance 5, 29-41.

Kester, W.C., 1991, Japanese takeovers: The contest for global corporate control, Harvard Business School Press, Boston, MA.

Korajczyk R.A., Lucas, D.J., and R.L. MCDonald, 1990. Understanding stock price behavior around the time of equity issues, in Asymmetric information, corporate finance, and investment, ed. by R. Glenn Hubbard, University of Chicago Press, Chicago.

Lease, R.C., R.W. Masulis, and J.R. Page, 1991, An irivestigation of market microsturcture impacts on event study returns, Journal of Finance 46, 1523-1537.

Lucas, D.J., and R.L. MCDonald, 1990, Equity issues and stock price dynamics, Joumal of Finance 45, 1019-1043.

Masulis, R.W., 1988, The debUequity choice, Ballinger Publishing Company.

Myers, S., and N. Majluf, 1984, Corporate financing and investment decisions when firms have information that investors do not have, Joumal of Financial Economics 13, 187-221.

Niimi, K., 1992a, Current trends in the Japanese corporate debt market, Japan Research Quarterly, 26-48. 
Niimi, K., 1992b. An analysis of bond rating in Japan: its history, status, and future, Japan Research Quarterly, 35-118.

Persons, J.C., 1994, Renegotiation and the impossibility of optimal investment, Review of Financial Studies $7,419-449$.

Porter, M.E., 1992, Capital choices: Changing the way America invests in industry, The CoNtinental Bank Joumal of Applied Corporate Finance 5, 4-16.

Saxonhouse, G.R., 1993, What does Japanese trade structure tell us about Japanese trade policy?. The Journal of Economic Perspectives 7, 21-44.

Scholes, M., and J. Williams, 1977, Estimating betas from nonsynchronous data, Joumal of Financial Economics 5, 309-328.

Shyam-Sunder, L., 1991, The stock-price effect of risky versus safe debt, Journal of Financial and Quantitative Analysis 26, 549-558.

Smith, C.W., 1986, Investment banking and the capital acquisition process, Joumal of Financial Economics 15, 3-29.

Wruck, K., 1989, Equity ownership concentration and firm value: Evidence from private equity financings, Joumal of Financial Economics 23, 3-28. 